DE

M E D I C I N A

T R O P I C A L

$\mathrm{DE}$

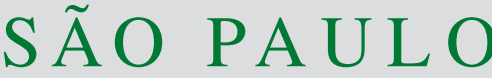

JOURNAL OF THE SÃO PAULO INSTITUTE OF TROPICAL MEDICINE

(1)Grupo Fleury, Automação, São Paulo, São Paulo, Brazil

(2)Universidade Federal de São Paulo, Departamento de Medicina, Laboratório de Virologia Clínica, Unidade de Doenças Infecciosas, São Paulo, São Paulo, Brazil

${ }^{(3)}$ Instituto Adolfo Lutz, Núcleo de Doenças Entéricas, Centro de Virologia, São Paulo, São Paulo, Brazil

(4)Universidade Estadual do Centro-Oeste, Guarapuava, Paraná, Brazil

Correspondence to: Marcel Leite Grupo Fleury, Automação, Av. General Waldomiro de Lima, 508, CEP 04344-070, São Paulo, SP, Brazil

E-mail: marcelleite83@gmail.com

Received: 27 October 2016

Accepted: 31 March 2017

\section{Rotavirus genotypes as etiological agents of diarrhoea in general populations of two geographic regions of Brazil}

\author{
Marcel Leite ${ }^{1,2}$, Rita de Cássia Compagnoli Carmona ${ }^{3}$, Emerson Carraro ${ }^{4}$, \\ Aripuanã Sakurada Aranha Watanabe ${ }^{2}$, Celso Francisco Hernandes \\ Granato ${ }^{1,2}$
}

\section{ABSTRACT}

Rotavirus is the main global cause of severe childhood diarrhoea among children. In 2006, Rotarix ${ }^{\circledR}$ (G1P [8]) was introduced into Brazil's National Immunization Program. The vaccine coverage rate was $84.4 \%$ in 2009. Evidences of increasing G2P[4] after 2006 opened up the discussion about the vaccine effectiveness to non-G1 strains. The aim of this study was to identify the circulating rotavirus genotypes in two Brazilian regions during 2009. A total of 223 positive samples by immunochromatography and latex agglutination assay from the Northeast (Bahia/Pernambuco States) and Southeast (São Paulo/Rio de Janeiro States) regions were included in the study. The samples were submitted to genotyping by nested-PCR according to VP7(G) and VP4(P) and 175 samples (78.5\%) were able to be characterized. Considering the characterization of VP7, the G-types detected were G1, G2, and G4 in the Northeast, and G2, G3, G5, and G9 in the Southeast. Considering the characterization of VP4, the P-types detected were P[4], P 8 ], and P[6]/P[9] in the Northeast and the Southeast. The most frequent mixed types found were G2P[4]/G2P[NT](81.4\%), G2P[6](5.2\%), G1P[6] $(5.2 \%)$ in the Northeast, and G2P[4]/G2P[NT](78.8\%), G2P[6](8.2\%), G9P[8](4.7\%) in the Southeast. Among immunized individuals whose age ranged from 0-4 years, the G2P[4]/ $\mathrm{G} 2 \mathrm{P}[\mathrm{NT}]$ genotype was identified in $91,0 \%$ of cases, and among non-immunized individuals of the same age, the G2P[4]/G2P[NT] genotype was identified in $85.7 \%$ of the cases. In accordance with the high level of vaccine coverage, the data suggest that the circulation of G2P[4] in these regions had a considerable increase after the introduction of Rotarix ${ }^{\circledR}$.

KEYWORDS: Rotavirus. Epidemiology. Genotype. Vaccine.

\section{INTRODUCTION}

Rotavirus infection is among the top six causes of severe diarrhoea in children, having already caused over two million deaths in children under five years of age ${ }^{1}$. It is transmitted via the fecal-oral route or through the consumption of contaminated water or food, with a minimum infectious dose of 10 virions $^{2}$.

Rotavirus strains can be classified into 8 groups or species (A-H); of these groups only A, B, C, and $\mathrm{H}$ can infect humans. Recently, two newer groups of rotavirus have been proposed ( $\mathrm{I}$ and $\mathrm{J})^{1,3-5}$. The molecular characterization of rotavirus is based on the gene that corresponds to VP4(P) and VP7 $(\mathrm{G})$ proteins. In Brazil, between the years of 2006 and 2009, the genotype G2 associated with P[4] or undefined VP4 was the most frequent strain. It was present in $49 \%, 66 \%, 85 \%$, and $37.5 \%$ of the samples analyzed each year, respectively. In contrast, genotypes G1 and G3 associated with P[8] or undefined VP4 have declined in frequency since $2005^{6}$. 
Rotarix ${ }^{\circledR}$ vaccine, which was included in the Brazilian immunization schedule in March 2006, consists of a monovalent preparation of the G1P[8] strain. From 2006 to 2012 , the vaccine coverage was $46.5 \%, 79.8 \%, 81.2 \%$, $84.4 \%, 83.0 \%, 87.1 \%$, and $86.4 \%$, respectively ${ }^{7}$. Although Rotarix $^{\circledR}$ has proven to be effective against infections by non-G1P[8] strains, recent studies have shown an increase in frequency and prevalence of the G2P[4] strain in Brazil and in Australia, and of the G9P[4] genotype in Mexico ${ }^{6,8-12}$ In this context, the aim of the present study is to describe the circulating rotavirus genotypes in two Brazilian regions in 2009.

\section{MATERIALS AND METHODS}

The 223 samples used in this study were collected during the year of 2009 in the Southeast region [States of São Paulo (SP - latitude: -2332' 51', longitude: -46³8'10”) and Rio de Janeiro (RJ - latitude: $-22^{\circ} 54^{\prime} 10^{\prime}$, longitude: $\left.-43^{\circ} 12^{\prime} 27^{\prime \prime}\right)$ ] and in the Northeast region [States of Bahia (BA - latitude: $-12^{\circ} 58^{\prime} 16^{\prime}$, longitude: $\left.-38^{\circ} 30^{\prime} 39^{\prime \prime}\right)$ and Pernambuco (PE - latitude: $-08^{\circ} 03$ ' 14", longitude: $-34^{\circ} 52$ ' 52")] of Brazil. These samples come from patients of all ages with diarrhoea whose physicians requested rotavirus screening in feces. We do not have information about the hospitalization of these patients, because samples were collected in the outpatient clinic (approved by the Ethics Committee - CEP 0771/11).

Immunochromatographic analyses (Vikia ${ }^{\circledR}$ Rota-Adeno, bioMérieux SA, Marcy- I'Étoile, France) were conducted in 223 rotavirus positive stool specimens. Viral RNA (dsRNA) was extracted in the QIAsymphony (QIAGEN, Hilden, Germany) instrument with the QIAsymphony ${ }^{\circledR}$ Virus/Bacteria Mini kit (QIAGEN, Hilden, Germany) from the supernatant of a suspension containing $10 \%$ of feces in PBS $(10 \mathrm{mmol} / \mathrm{L}$ of sodium phosphate and $0.15 \mathrm{~mol} / \mathrm{L}$ of sodium chloride with a $\mathrm{pH}$ from 7.2 to 7.4 ). VP7 and VP4 genotyping were obtained with two PCR reactions for each one of the genes. In the first reaction, BEG/END (VP7) and $\mathrm{CON} 3 / \mathrm{CON} 2$ (VP4) primer pools were used, whereas in the second one, pools 9CON1/9T1-1/9T1-2/9T-3P/9T-4/ FT5/9T-9B (VP7) and CON3/2T-1/3T-1/1T-1/4T-1 (VP4) were employed. In the first PCR (RT-PCR), the mixture ( $5 \mu \mathrm{L}$ dsRNA with $3 \mu \mathrm{L}$ DMSO) was heated to $93{ }^{\circ} \mathrm{C}$ for $3 \mathrm{~min}$, and cooled in ice bath for $5 \mathrm{~min}$. Then, $42 \mu \mathrm{L}$ of the following mixture were added $\left[14.2 \mu \mathrm{L} \mathrm{H}_{2} \mathrm{O}, 16 \mu \mathrm{L}\right.$ mix dNTP (1.25 mM of each dNTP), $5 \mu \mathrm{L} 10 \mathrm{x}$ reaction buffer (200 mM Tris-HCl/pH-8.4/500 mM KCl), $5 \mu \mathrm{L} \mathrm{MgCl}_{2}$ (50 mM), $1 \mu \mathrm{L}$ primer pool ( $20 \mu \mathrm{M}$ of each primer), $0.4 \mu \mathrm{L}$ Platinum Taq DNA polymerase (Invitrogen, California, USA) and $0.4 \mu \mathrm{L}$ Reverse Transcriptase (Superscript II
- Invitrogen, California, USA)]. After that, the mixture was submitted to the following conditions: $42^{\circ} \mathrm{C} / 60 \mathrm{~min}$, 35 cycles $\left(94{ }^{\circ} \mathrm{C} / 1 \mathrm{~min}, 42^{\circ} \mathrm{C} / 2 \mathrm{~min}\right.$, and $72{ }^{\circ} \mathrm{C} / 1 \mathrm{~min}$ ), and $72{ }^{\circ} \mathrm{C} / 5 \mathrm{~min}$. In the second PCR (semi-nested-PCR), $1 \mu \mathrm{L}$ of the cDNA formed in the RT-PCR was added to $24 \mu \mathrm{L}$ of the mixture $\left[10.3 \mu \mathrm{L} \mathrm{H} \mathrm{H}_{2} \mathrm{O}, 8 \mu \mathrm{L}\right.$ mix dNTP $(1.25 \mathrm{mM}$ of each dNTP), $2.5 \mu \mathrm{L} 10 \mathrm{x}$ reaction buffer $(200 \mathrm{mM}$ Tris-HCl/pH-8.4/500 mM KCl), $2.5 \mu \mathrm{L} \mathrm{MgCl}_{2}(50 \mathrm{mM}$ ), $0.5 \mu \mathrm{L}$ primer pool $(20 \mu \mathrm{M}$ of each primer $), 0.2 \mu \mathrm{L}$ Platinum Taq DNA polymerase (Invitrogen, California, USA)]. The mixture was then submitted to the following conditions: 25 cycles $\left(94{ }^{\circ} \mathrm{C} / 1 \mathrm{~min}, 50{ }^{\circ} \mathrm{C} / 2 \mathrm{~min}\right.$, and $72{ }^{\circ} \mathrm{C} / 1 \mathrm{~min}$ ), and $72{ }^{\circ} \mathrm{C} / 5 \mathrm{~min}$. For all reactions, both negative $\left(\mathrm{H}_{2} \mathrm{O}\right)$ and positive (genotyped sample) controls were used. PCR products were analyzed by electrophoresis in $1.2 \%$ GelRed $^{\mathrm{TM}}$ - Biotium-stained agarose gel (GelRed ${ }^{\mathrm{TM}}$ Biotium, California, USA) and genotype identification relied on the size of the DNA sequence obtained, using bands with previously defined molecular weight sizes as a reference $[1 \mathrm{~Kb}$ plus and $50 \mathrm{pb}$ DNA ladder (Invitrogen, California, USA)] $]^{13-15}$.

\section{RESULTS AND DISCUSSION}

Of the 223 samples, 48 were not PCR-positive for rotavirus, whereas 175 had the VP7 and/or VP4 genotypes identified. There was no significant difference of age, sex, place of origin and time of year of collection between the 48 samples that did not have the presence of viral RNA confirmed and the other 175 genotyped samples. The 223 stool specimens were collected from patients for rotavirus testing at the laboratory. The samples were kept refrigerated $\left(4-8^{\circ} \mathrm{C}\right.$ ) for 4-7 days until their inclusion in this study, when they were then frozen at $-20^{\circ} \mathrm{C}$.

Rotavirus testing is performed through immunochromatography, which detects the presence of the VP6 protein. Therefore, sample stability is less critical than in genotype analysis, since RNA degrades in temperatures above $-20{ }^{\circ} \mathrm{C}$. In 2008 , Téllez et al ${ }^{16}$ observed that the specificity of the Vikia ${ }^{\circledR}$ Rota-Adeno kit was $24.2 \%$, lower than the PCR's. Thus, the absence of RNA in those 48 samples may be related to sample stability differences between the two methods and to the lower specificity of immunochromatography. It is also important to note that $81.3 \%$ of the samples were from patients from 0-4 years of age and, in this age group, stool collection is more complicated and results are drawn from a reduced sample volume, making it harder to achieve PCR viral RNA stability. The absence of viral RNA may also be due to the presence of PCR inhibitors in the feces.

Of the 175 genotyped samples, $50.9 \%$ belonged to 
women, $45 \%$ belonged to men, and $4 \%$ did not have the gender identified. Regarding the age group, 59.4\% $(-104 / 175)$ were children aged from 0-10 years, and of those $48(27.4 \% ; \mathrm{n}=48 / 175)$ were children from $0-2$ years (Table 1). The average age observed was of 15.6 years old, while the mean age was six years old. Concerning the Brazilian state of origin, 52.6\% (-92/175) were from the Northeast (Pernambuco/Bahia States) and 47.4\% (83/175) from the Southeast (São Paulo/Rio de Janeiro States). As for the time of collection, $58.9 \%$ (103/175) were collected in the winter, $14.9 \%(-26 / 175)$ in the summer, $13.1 \%$ $(-23 / 175)$ in the spring, $10.9 \%(-19 / 175)$ in the autumn, and 2.3\% (- 4/175) in an unidentified season (Figure 1). Rotavirus infection was observed in all age groups, but a higher incidence was found in children aged $0-2$ years, confirming the suspicion that this infection is still more frequent in this age group of the population, and highlighting the need of effective vaccination. Infection in adults is mostly associated with the virus being transmitted

Table 1 - Classification of samples with VP7 and/or VP4 genotype identified by age group

\begin{tabular}{lc}
\hline Age group & Number of samples \\
\hline 0 - 2 years & 48 \\
3 - 4 years & 25 \\
5 - 10 years & 31 \\
11 - 20 years & 12 \\
21 - 30 years & 19 \\
31 - 40 years & 8 \\
41 - 50 years & 7 \\
$>50$ years & 16 \\
No information & 9 \\
\hline TOTAL & 175 \\
\hline
\end{tabular}

to them by infected children. Therefore, effective childhood vaccination may cause an indirect effect of reducing the number of infected adults ${ }^{10,12,17}$. About the distribution throughout the year, $69.7 \%$ of the genotyped samples were concentrated in the colder and drier seasons. In this context, the distribution of cases throughout the year seems to be similar to that of temperate climate countries, where infections happen predominantly in the colder and drier months. The present study suggests, however, that rotavirus infection in these regions of Brazil is in-between the period observed in tropical climate countries where the cases are spread throughout the year, what is observed in temperate climate countries. Focusing on each one of the regions, we noticed that the Northeast region (Pernambuco/ Bahia States) typically presenting tropical weather with higher average temperatures and milder temperatures in the winter has a higher concentration of cases in the winter, whereas the Southeast region (São Paulo/Rio de Janeiro States), characterized by lower temperatures in the winter had more evenly spread cases throughout the year. Therefore, one may state that curiously enough the Northeast region demonstrated a profile that is more similar to that of temperate climate countries. In agreement with this fact, Silva et al. ${ }^{18}$ observed that rotavirus infection in the State of Pernambuco in 2007 and 2008 also happened more frequently from May to September (autumn and winter). As a whole, it is expected that the general sanitary conditions are better in the Southeast region than in the Northeast region.

VP7 genotyping revealed the circulation of G1, G2, G3, G4, G5, and G9, though in 6 cases VP7 genotyping was not possible. The dominant VP7 genotype was G2 (88.0\%; -154/175), followed by G1 (4.6\%; -8/175) (Table 2). VP4 genotyping showed genotypes P[4], P[6], $\mathrm{P}[8]$, and $\mathrm{P}[9]$, though the genotyping of 26 samples

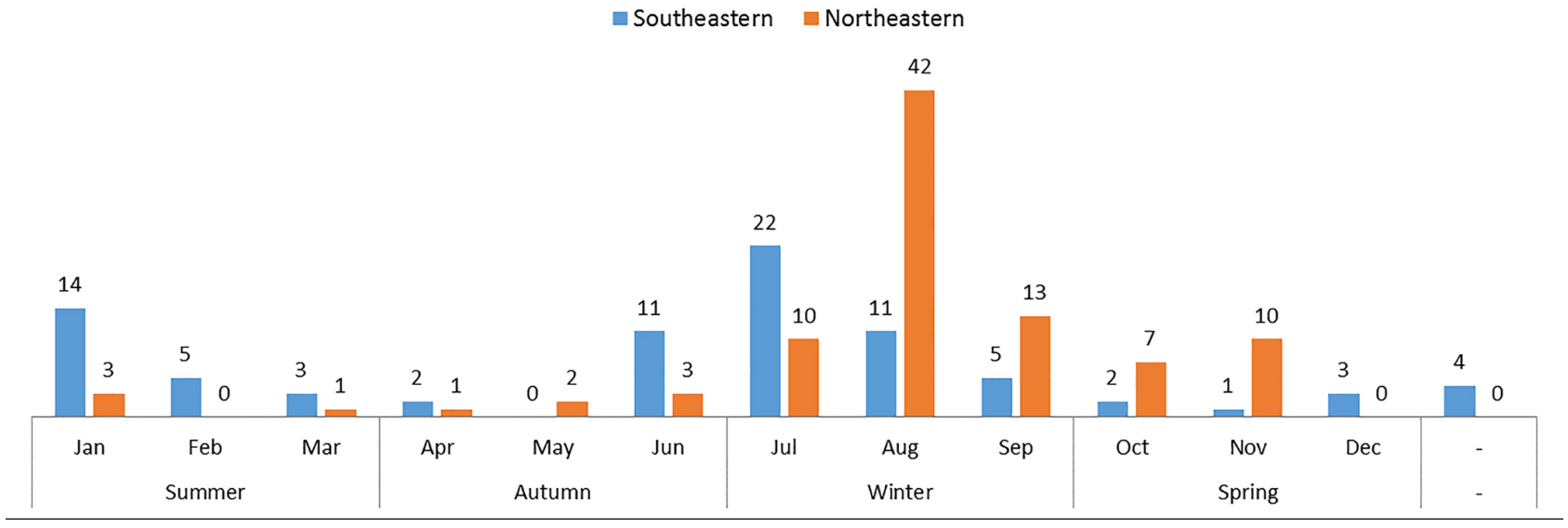

Figure 1 - Classification of samples from the Southeast and Northeast regions of Brazil that were PCR-positive for rotavirus by date of collection 
Table 2 - Classification of samples confirmed as rotaviruspositive by VP7 genotype

\begin{tabular}{lc}
\hline Genotype & Number of samples \\
\hline G2 & 154 \\
G1 & 8 \\
Unidentified & 6 \\
G9 & 5 \\
G3 & 1 \\
G4 & 1 \\
G5 & 1 \\
\hline
\end{tabular}

was not possible. The dominant VP4 genotype was P[4] (72.0\%; $n=126 / 175)$, followed by P[6] (10.3\%; -18/175) (Table 3). Additional data are presented in Tables 2 and 3. Concerning the combinations of VP7 and VP4, 69.1\% $(-121 / 175)$ corresponded to G2P[4], $14.3 \%(-25 / 175)$ to G2 with unidentified VP4, 6.9\% (-12/175) to G2P[6], and $13.7 \%(-24 / 175)$ to other strains (G1P[6], G9P [8], P[4] with unidentified VP7, G1P[8], P[8] with unidentified VP7, G1 with unidentified VP4, G1P[4], G3P[9], G4P[6], G5P[8], G9 with unidentified VP4, and P[9] with unidentified VP7) (Table 4). In the Northeast region, the most common rotavirus strains were G2P[4] (72.8\%; -67/92), G2 with unidentified VP4 (13.0\%; -12/92), and G2P[6] (5.4\%; $-5 / 92)$, whereas in the Southeast, the most frequently found strains were: G2P[4] $(65.1 \% ; n=54 / 83), \mathrm{G} 2$ with unidentified VP4 (15.7\%; $n=13 / 83)$, and G2P[6] (8.4\%; $\mathrm{n}=7 / 83$ ) (Table 5). As for the presence of different genotypes in the same patient, there were four samples of G2P[4]P[6] (Pernambuco, São Paulo, and Bahia States), one of G1P[4] P[6] (Bahia State), one of G2/G9 with unidentified VP4 (SP), and one of P[8]/P[9] with unidentified VP7 (Bahia State).

Table 3 - Classification of samples confirmed as rotaviruspositive by VP4 genotype

\begin{tabular}{lc}
\hline Genotype & Number of samples \\
\hline $\mathrm{P}[4]$ & 126 \\
Unidentified & 26 \\
$\mathrm{P}[6]$ & 18 \\
$\mathrm{P}[8]$ & 9 \\
$\mathrm{P}[9]$ & 2 \\
\hline
\end{tabular}

A pool of G1-, G2-, G3-, G4-, G5- and G9-specific primers was used for the VP7 genotyping. Of the 175 genotyped samples, six did not have the VP7 type identified. There was gene amplification in one of those samples in the first PCR, but not in the second one, which indicates that
Table 4 - Classification of samples confirmed as rotaviruspositive by VP7-VP4 combination. (* Unidentified P genotype/** Unidentified G genotype)

\begin{tabular}{|c|c|}
\hline Genotype & Number of samples \\
\hline G2P[4] & 121 \\
\hline $\mathrm{G} 2 \mathrm{P}^{*}$ & 25 \\
\hline G2P[6] & 12 \\
\hline G1P[6] & 5 \\
\hline G9P[8] & 4 \\
\hline$G^{\star \star} P[4]$ & 4 \\
\hline G1P[8] & 2 \\
\hline$G^{\star \star} P[8]$ & 2 \\
\hline $\mathrm{G}_{1} \mathrm{P}^{*}$ & 1 \\
\hline G1P[4] & 1 \\
\hline G3P[9] & 1 \\
\hline G4P[6] & 1 \\
\hline G5P[8] & 1 \\
\hline $\mathrm{G9P}^{*}$ & 1 \\
\hline$G^{\star \star} P[9]$ & 1 \\
\hline
\end{tabular}

Table 5 - Classification of rotavirus strains by region of origin (Brazil) (* Unidentified P genotype/** Unidentified G genotype)

\begin{tabular}{|c|c|c|}
\hline Genotype & $\begin{array}{c}\text { Northeast } \\
\text { Number of samples }\end{array}$ & $\begin{array}{c}\text { Southeast } \\
\text { Number of samples }\end{array}$ \\
\hline G2P[4] & 67 & 54 \\
\hline G2P* & 12 & 13 \\
\hline G2P[6] & 5 & 7 \\
\hline G1P[6] & 5 & - \\
\hline G9P[8] & - & 4 \\
\hline$G^{* *} P[4]$ & 1 & 3 \\
\hline G1P[8] & 2 & - \\
\hline$G^{* \star} P[8]$ & 1 & 1 \\
\hline G1P* & 1 & - \\
\hline G1P[4] & 1 & - \\
\hline G4P[6] & 1 & - \\
\hline $\mathrm{G}^{* *} \mathrm{P}[9]$ & 1 & - \\
\hline G3P[9] & - & 1 \\
\hline G5P[8] & - & 1 \\
\hline G9P* $^{*}$ & - & 1 \\
\hline
\end{tabular}

the genotype is not among those chosen as the focus of this study, characterizing it as emerging or of low circulation, since this study focuses on the top circulating genotypes in the Brazilian population ${ }^{9,19}$. The other five cases had no VP7 gene amplification in the first or second PCR, with the presence of the virus beingconfirmed by VP4 genotyping. 
In the studied population, VP7 genotyping revealed the circulation of all investigated genotypes (G1, G2, G3, G4, G5 and G9), with G2 and G1 as the most frequent ones. On a global scale, Santos and Hoshino ${ }^{20}$ noticed that from 1989 to 2004, the dominant VP7 genotype was G1. In Brazil, Gurgel et al. ${ }^{9}$ noticed that before the inclusion of Rotarix ${ }^{\circledR}$ in the immunization schedule, from 1986 to 2006, the most frequent VP7 genotype was G1, representing $44 \%$ of the total, followed by G9 with $19 \%$ and G2 with $17 \%$. Still in Brazil, Leite et al. ${ }^{19}$ observed that from 1982 to 2005 G1 was the most common VP7 genotype, representing $43 \%$ of the cases and G2 representing 9\%, whereas from 2006 to 2007 (approximately one year after the implementation of Rotarix ${ }^{\oplus}$ ) G1 had its frequency reduced to only $3 \%$ of the cases and G2 became the most frequent genotype, representing $74 \%$ of the cases, followed by G9 with $11 \%$. Focusing on the G2 frequency only, Leite et al. ${ }^{19}$ observed that from 1982 to 1995 this genotype was identified in $26 \%$ of the cases; from 1996 to 2005 , this rate dropped to $2 \%$, and from 2006 to 2007 , it increased to $74 \%$. One could assume that the VP7 profile observed in this study is similar to the one seen after the implementation of Rotarix ${ }^{\circledR}$.

The VP4 genotyping used the same methodology as the VP7 genotyping, with the primer pool of the second PCR corresponding to $\mathrm{P}[4], \mathrm{P}[6], \mathrm{P}[8]$, and $\mathrm{P}[9]$ genotypes. Of the 175 genotyped samples, 26 had unidentified VP4 and turned out negative in the first and second PCR rounds, being confirmed as rotavirus-positive by VP7 identification. The VP4 genotyping revealed the circulation of four of the studied genotypes (P[4], P[6], P[8], and P[9]), with P[4] as the most common one (70\%). Santos and Hoshino 20 noted that from 1989 to 2004 the two most common VP4 genotypes in the world were P[8] and P[4]. Focusing on the period between 1986 and 2006 in Brazil, Gurgel et al. ${ }^{9}$ stated that before the introduction of Rotarix ${ }^{\circledR}$ in the official immunization schedule, $\mathrm{P}[8], \mathrm{P}[4]$, and $\mathrm{P}[6]$ had frequency rates of $75 \%, 10 \%$ and $6 \%$, respectively. In a different study, Leite et al. ${ }^{19}$ analyzed the Brazilian population from 1982 to 2007 and named the one-year period from 2006 to 2007 as the post-Rotarix ${ }^{\circledR}$ period. From 1982 to 2005, P[8] was present in approximately $70 \%$ of the cases and P[4] in 9\%. From 2006 to 2007, in contrast, $\mathrm{P}[4]$ was identified in approximately $70 \%$ of the cases and $\mathrm{P}[8]$ in about $15 \%$. Considering the descriptions in the literature, one could say that the prevalent profile observed in this study for the VP4 genotypes resembles that of the post-Rotarix ${ }^{\circledR}$ period.

Of the total genotyped samples, $3 \%$ and $15 \%$ were PCR negative for VP7 and VP4, respectively. This may be related to genetic drifts, genomic rearrangements (shifts), or genetic reassortments that take place in the primer binding site. ${ }^{21-29}$.
As for the historically usual VP7-VP4 combinations (G1P[8], G2P[4], G3P[8] and G4P[8]), there were no cases of G3P[8] and G4P[8], and only two of G1P[8]. $\mathrm{G} 2 \mathrm{P}[4]$, on the other hand, it was observed in $69 \%$ of the samples. G9P[8], which was recently found with a higher frequency and classified as a usual strain, was reported in only $2.3 \%$ of the samples. Only one case of G5P[8] was found. Literature data indicate that G1P[8] was the most prevalent strain in the world from 1989 to 2004. In Brazil, G1P[8], G9P[8], G2P[4], G3P[8], G4P[8] and G5P[8] were, in ascending order, the most common strains from 1982 to 2005. After 2006, the year in which Rotarix ${ }^{\circledR}$ was included in the Brazilian immunization schedule, there was a change in the circulation of strains. G2P[4] took the lead as the most frequent type, while G1P[8] ranked third., ${ }^{9,11,19,20,30}$ Approximately $5 \%$ of rotavirus cases are caused by uncommon combinations of VP7 and VP4. In this study, we found the following uncommon combinations: G1P[4], G1P[6] G2P[6], G3P[9], and G4P[6], which altogether accounted for $10 \%$ of the cases $(n=18)$.

Literature data suggest that the infection by two or more genotypes of rotavirus (mixed infection) has a frequency rate of $15 \%$ in South American countries. It is believed that those infections occur more often in regions where there is greater diversity and circulation of uncommon strains ${ }^{20,31}$. In this study, seven cases of mixed infections (4\%) were found. Of those, four samples had $\mathrm{P}[4] / \mathrm{P}[6]$ associated with G2, one had P[4]/P[6] associated with G1, one had G2/G9 associated with unidentified VP4, and one sample had $\mathrm{P}[8] / \mathrm{P}[9]$ associated with unidentified VP7.

Comparing the regions of study (Southeast and Northeast) by genotype, we see that the three most frequent ones (G2P [4], G2 with unidentified VP4, and G2P[6]) have similar rates in both regions, representing approximately $87 \%$ of the samples. Among the historically usual strains, G1P[8] was found only in two cases in the Northeast region, G2P[4] was the dominant type in both regions, and G9P[8] and G5P[8] were found only in the Southeast region in approximately $5 \%$ and $1 \%$ of the samples, respectively. As for the uncommon VP7-VP4 combinations, G1P[6], G1P[4], G4P[6], and G2P[6] were circulating in approximately $12 \%$ of the samples from the Northeast, whereas G3P[9] and G2P[6] were seen in about 9\% of the samples from the Southeast. Regarding cases of mixed infection, there was a $5 \%$ rate in the Northeast samples against $2 \%$ in the Southeast ones. In the Northeast group, there were three samples with G2-associated $\mathrm{P}[4] / \mathrm{P}[6]$, one with G1-associated P[4]/P[6], and one with P[8]/P[9] associated with an unidentified VP7. In the Southeast group, there was one sample with G2/G9 associated with unidentified VP4 and one with G2-associated P[4]/P[6]. 
Table 6 - Reports by selected authors on the circulation of rotavirus strains

\begin{tabular}{|c|c|c|c|}
\hline Location & Period & Observed & Reference \\
\hline Sergipe & Nov./06 - Feb./07 & G2P[4] - observed in $100 \%$ of the samples & Gurgel et al. ${ }^{8}$ \\
\hline Sergipe & Oct./06 - Apr./08 & G2P $[4]-$ observed in $95 \%$ of the samples & Gurgel et al. ${ }^{32}$ \\
\hline Recife & Mar./06 - May/07 & G2 - observed in $100 \%$ of the samples & Nakagomi et al. ${ }^{33}$ \\
\hline Rio de Janeiro & $2005-2007$ & G2P[4] - 1.4\% (2005) / 44\% (2006) / 96\% (2007) & Carvalho-Costa et al. ${ }^{34}$ \\
\hline Parauapebas & $2006-2008$ & G2P $[4]-$ observed in $90 \%$ of the samples & Mascarenhas et al. ${ }^{35}$ \\
\hline São Paulo & $2006-2009$ & $\begin{array}{c}\text { G9P[8] - dominant type in } 2006 \\
\text { G2P[4] - dominant type in } 2007 \text { / } 2008 \text { / } 2009\end{array}$ & Cilli et al. ${ }^{11}$ \\
\hline São Paulo & $2006-2008$ & $\begin{array}{l}\text { In hospitalized children: G2P[4] - 15\% (2006) / } \\
\quad 70 \%(2007) / 100 \%(2008)\end{array}$ & Sáfadi et al. ${ }^{36}$ \\
\hline Belém & $2008-2009$ & In hospitalized children: G2P[4] predominance & Justino et $a .^{37}$ \\
\hline Minas Gerais & $2009-2010$ & G2P $[4]$ predominance & Dulgheroff et al. ${ }^{38}$ \\
\hline Curitiba & $2001-2008$ & In hospitalized patients: G2P[4] predominance after 2006 & Pereira et al. ${ }^{39}$ \\
\hline 18 Brazilian states & $2005-2009$ & $\begin{array}{c}\text { G9 - dominant type in } 2005(52 \%) \\
\text { G2P }[4]-49 \%(2006) / 66 \%(2007) / \\
85 \%(2008) / 37 \%(2009)\end{array}$ & Carvalho-Costa et al. ${ }^{6}$ \\
\hline Australia & 2007 - 2009 & $\begin{array}{l}\text { Increase in G2P[4] rates in most states where Rotarix } ® \text { is } \\
\text { in use }\end{array}$ & Kirkwood et al. ${ }^{40}$ \\
\hline
\end{tabular}

Official data from the Brazilian Ministry of Health reveal that in 2009 the Rotarix ${ }^{\circledast}$ vaccine coverage in the states of Pernambuco, Bahia, Rio de Janeiro, and São Paulo was $88.6 \%, 78.5 \%, 80.5 \%$, and $89.1 \%$, respectively ${ }^{7}$. Corroborating literature findings (Table 6) for the post-Rotarix ${ }^{\circledR}$ period, this study found an approximate predominance of $83 \%$ of $\mathrm{G} 2$ associated with $\mathrm{P} 4$ or with an unidentified VP4, an absence of G3P[8] and G4P [8], and only two cases of G1P[8] (1\% of the studied samples), which shows a significant increase in the G2P[4] predominance. Selective pressure exerted by the vaccination has eventually led the unvaccinated population to be affected by the strains that are predominant among vaccinated individuals.

\section{CONCLUSION}

Of the VP7 genotypes found, only G2 was circulating in both of the regions studied. G1 and G4 were circulating only in the Northeast region (Bahia and Pernambuco States) whereas G3, G5, and G9 were circulating only in the Southeast region (São Paulo and Rio de Janeiro States). The VP4 genotypes that were found (P[4], P[6], P[8] and $\mathrm{P}[9])$, on the other hand, were all circulating in both regions. G2P[4] proved to be the most common combination in both regions (Bahia and Pernambuco - 72.8\%; São Paulo and Rio de Janeiro $-65.1 \%$ ). The G2P[4] predominance was seen in a population with a reasonable coverage of Rotarix $^{\circledast}$, but further studies are needed to understand the reasons that may have led to this increase of genotype two and to define whether or not the vaccine formulation should be modified. According to our data, multivalent vaccines might have to be proposed in order to be useful to different regions of the country.

\section{ACKNOWLEDGEMENTS}

The authors thank the colleagues from the UNIFESP virology laboratory, from the Fleury Group's Institute for Research and Development, and from the Adolfo Lutz Institute, for their contribution and support in the development of this study.

We would also like to thank the Federal University of São Paulo and the Fleury Group for their technical and financial support.

\section{REFERENCES}

1. Estes MK, Greenberg HB. Rotaviruses. In: Knipe DM, Howley PM, editors-in-chief Field's virology. 6th ed. Philadelphia: Wolters Kluwer Health/Lippincott Williams \& Wilkins; 2013.

2. Ward RL. Mechanisms of protection against rotavirus in humans and mice. J Infect Dis. 1996;174 Suppl 1:S51-8.

3. Matthijnssens J, Otto PH, Ciarlet M, Desselberger U, Van Ranst M, Johne R. VP6-sequence-based cutoff values as a criterion for rotavirus species demarcation. Arch Virol. 2012;157:117782.

4. Mihalov-Kovács E, Gellért Á, Marton S, Farkas SL, Fehér E, Oldal M, et al. Candidate new rotavirus species in sheltered dogs, Hungary. Emerg Infect Dis. 2015;21:660-3. 
5. Bányai K, Kemenesi G, Budinski I, Földes F, Zana B, Marton $\mathrm{S}$, et al. Candidate new rotavirus species in Schreiber's bats, Serbia. Infect Genet Evol. 2017;48:19-26.

6. Carvalho-Costa FA, Volotão EM, de Assis RM, Fialho AM, de Andrade JS, Rocha LN, et al. Laboratory-based rotavirus surveillance during the introduction of a vaccination program, Brazil, 2005-2009. Pediatr Infect Dis J. 2011;30 Suppl 1:S35-41.

7. Brasil. Ministério da Saúde. Datasus. Informações de Saúde. [cited 2017 Apr 4]. Available from: http://tabnet.datasus.gov.br/cgi/ tabcgi.exe?pni/cnv/cpniuf.def

8. Gurgel RQ, Cuevas LE, Vieira SC, Barros VC, Fontes PB, Salustino EF, et al. Predominance of rotavirus P[4]G2 in a vaccinated population, Brazil. Emerg Infect Dis. $2007 ; 13: 1571-3$

9. Gurgel RQ, Cunliffe NA, Nakagomi O, Cuevas LE. Rotavirus genotypes circulating in Brazil before national rotavirus vaccination: a review. J Clin Virol. 2008;43:1-8.

10. Patel MM, Steele D, Gentsch JR, Wecker J, Glass RI, Parashar UD. Real-world impact of rotavirus vaccination. Pediatr Infect Dis J. 2011;30 Suppl 1:S1-5.

11. Cilli A, Luchs A, Morillo SG, Costa FF, Carmona RC, Timenetsky MC. Characterization of rotavirus and norovirus strains: a 6-year study (2004-2009). J Pediatr (Rio J). 2011;87:445-9.

12. Lopman BA, Payne DC, Tate JE, Patel MM, Cortese MM, Parashar UD. Post-licensure experience with rotavirus vaccination in high and middle income countries; 2006 to 2011. Curr Opin Virol. 2012;2:434-42.

13. Gouvea V, Glass RI, Woods P, Taniguchi K, Clark HF, Forrester B. Polymerase chain reaction amplification and typing of rotavirus nucleic acid from stool specimens. J Clin Microbiol. 1990;28:276-82.

14. Gentsch JR, Glass RI, Woods P, Gouvea V, Gorziglia M, Flores $\mathrm{J}$, et al. Identification of group A rotavirus gene 4 types by polymerase chain reaction. J Clin Microbiol. 1992;30:1365-73.

15. Espínola EE, Parra GI, Russomando G, Arbiza J. Genetic diversity of the VP4 and VP7 genes affects the genotyping of rotaviruses: analysis of Paraguayan strains. Infect Gen Evol. 2008;8:94-9.

16. Téllez CJ, Montava R, Ribes JM, Tirado MD, Buesa J. Evaluación de dos equipos inmunocromatográficos comerciales para el diagnóstico rápido de la infección por rotavirus. Rev Argent Microbiol. 2008;40:167-70.

17. Anderson EJ, Shippee DB, Weinrobe MH, Davila MD, Katz $\mathrm{BZ}$, Reddy S, et al. Indirect protection of adults from rotavirus by pediatric rotavirus vaccination. Clin Infect Dis. 2013;56:755-60.

18. Silva ML, Souza JR, Melo MM. Prevalência de rotavírus em crianças atendidas na rede pública de saúde do estado de Pernambuco. Rev Soc Bras Med Trop. 2010;43:548-51.

19. Leite JP, Carvalho-Costa FA, Linhares AC. Group A rotavirus genotypes and the ongoing Brazilian experience: a review. Mem Inst Oswaldo Cruz. 2008;103:745-53.
20. Santos N, Hoshino Y. Global distribution of rotavirus serotypes/ genotypes and its implication for the development and implementation of an effective vaccine. Rev Med Virol. 2005; 15:29-56.

21. Taniguchi K, Urasawa S. Diversity in rotavirus genomes. Semin Virol.1995;6:123-31.

22. Unicomb LE, Podder G, Gentsch JR, Woods PA, Hasan KZ, Faruque AS, et al. Evidence of high-frequency genomic reassortment of group A rotavirus strains in Bangladesh: emergence of type G9 in 1995. J Clin Microbiol. 1999;37:1885-91.

23. Honma S, Chizhikov V, Santos N, Tatsumi M, Timenetsky MC, Linhares AC, et al. Development and validation of DNA microarray for genotyping group A rotavirus VP4 (P[4], P[6], $\mathrm{P}[8], \mathrm{P}[9]$, and P[14]) and VP7 (G1 to G6, G8 to G10, and G12) genes. J Clin Microbiol. 2007;45:2641-8.

24. Schnepf N, Deback C, Dehee A, Gault E, Parez N, Garbag-Chenon A. Rearrangements of rotavirus genomic segment 11 are generated during acute infection of immunocompetent children and do not occur at random. J Virol. 2008;82:3689-96.

25. Santos N, Honma S, Timenetsky MC, Linhares AC, Ushijima $\mathrm{H}$, Armah GE, et al. Development of a microtiter plate hybridization-based PCR-enzyme-linked immunosorbent assay for identification of clinically relevant human group A rotavirus G and P genotypes. J Clin Microbiol. 2008;46:462-9.

26. Ghosh S, Kobayashi N. Whole-genomic analysis of rotavirus strains: current status and future prospects. Future Microbiol. 2011;6:1049-65.

27. Tatte VS, Chitambar SD. Diversity in the VP7 encoding genes of rotavirus strains isolated from adolescent and adult cases of acute gastroenteritis. J Med Virol. 2012;84:1481-8.

28. Ianiro G, Heylen E, Delogu R, Zeller M, Matthijnssens J, Ruggeri FM, et al. Genetic diversity of G9P[8] rotavirus strains circulating in Italy in 2007 and 2010 as determined by whole genome sequencing. Infect Genet Evol. 2013;16:426-32.

29. Nakagomi T, Doan YH, Dove W, Ngwira B, Iturriza-Gómara M, Nakagomi O, et al. G8 rotaviruses with conserved genotype constellations detected in Malawi over 10 years (1997-2007) display frequent gene reassortment among strains cocirculating in humans. J Gen Virol. 2013;94:1273-95.

30. Carmona RC, Timenetsky MC, Morillo SG, Richtzenhain LJ. Human rotavirus serotype G9, São Paulo, Brazil, 1996-2003. Emerg Infect Dis. 2006;12:963-8.

31. Gentsch JR, Laird AR, Bielfelt B, Griffin DD, Banyai K, Ramachandran M, et al. Serotype diversity and reassortment between human and animal rotavirus strains: implications for rotavirus vaccine programs. J Infect Dis. 2005;192 Suppl 1:S146-59.

32. Gurgel RG, Bohland AK, Vieira SC, Oliveira DM, Fontes PB, Barros VF, et al. Incidence of rotavirus and all-cause diarrhea in northeast Brazil following the introduction of a national vaccination program. Gastroenterology. 2009;137:1970-5. 
33. Nakagomi T, Cuevas LE, Gurgel RG, Elrokhsi SH, Belkhir YA, Abugalia M, et al. Apparent extinction of non-G2 rotavirus strains from circulation in Recife, Brazil, after the introduction of rotavirus vaccine. Arch Virol. 2008;153:591-3.

34. Carvalho-Costa FA, Araújo IT, Santos de Assis RM, Fialho AM, de Assis Martins CM, Bóia MN, et al. Rotavirus genotype distribution after vaccine introduction, Rio de Janeiro, Brazil. Emerg Infect Dis. 2009;15:95-7.

35. Mascarenhas JD, Lima CS, de Oliveira DS, Guerra SF, Maestri RP, Gabbay YB, et al. Identification of two sublineages of genotype G2 rotavirus among diarrheic children in Parauapebas, Southern Pará State, Brazil. J Med Virol. 2010;82:712-9.

36. Sáfadi MA, Berezin EN, Munford V, Almeida FJ, de Moraes JC, Pinheiro CF, et al. Hospital-based surveillance to evaluate the impact of rotavirus vaccination in São Paulo, Brazil. Pediatr Infect Dis J. 2010;29:1019-22.

37. Justino MC, Linhares AC, Lanzieri TM, Miranda Y, Mascarenhas JD, Abreu E, et al. Effectiveness of the monovalent G1P[8] human rotavirus vaccine against hospitalization for severe G2P[4] rotavirus gastroenteritis in Belém, Brazil. Pediatr Infect Dis J. 2011;30:396-401.

38. Dulgheroff AC, Figueiredo EF, Moreira LP, Moreira KC, Moura LM, Gouvêa VS, et al. Distribution of rotavirus genotypes after vaccine introduction in the Triângulo Mineiro region of Brazil: 4-Year follow-up study. J Clin Virol. 2012;55:67-71.

39. Pereira LA, Ferreira CE, Turchetto GD, Nogueira MB, Vidal LR, Cruz CR, et al. Molecular characterization of rotavirus genotypes in immunosuppressed and non-immunosuppressed pediatric patients. J Pediatr (Rio J). 2013;89:278-85.

40. Kirkwood CD, Boniface K, Barnes GL, Bishop RF. Distribution of rotavirus genotypes after introduction of rotavirus vaccines, Rotarix ${ }^{\circledR}$ and RotaTeq ${ }^{\circledR}$, into the National Immunization Program of Australia. Pediatr Infect Dis J. 2011;30 Suppl 1:S48-53. 